\title{
Acute respiratory symptoms and its associated factors among mothers who have under five-years-old children in northwest, Ethiopia
}

Zewudu Andualem', Zelalem Nigussie Azene ${ }^{2}$, Jember Azanaw ${ }^{1 *}$, Asefa Adimasu Taddese ${ }^{3}$ and Henok Dagne ${ }^{1}$

\begin{abstract}
Background: Poor air quality of the household is likely to be the largest public health concern in resourceconstrained countries. Exposure to household air pollution, poor working environment, and fuel type used at household level have been associated with respiratory symptoms. This study aimed to assess acute respiratory symptoms and its associated factors among mothers who have under five-years-old children in Gondar city, northwest Ethiopia.
\end{abstract}

Method: A cross-sectional study was carried out from February 15, 2019 to June 20, 2019. Study participants were selected using simple random sampling, and data were collected via face-to-face interviews. Binary logistic regression analysis was used to test the association of explanatory and outcome variables. Variables with $p<0.05$ were considered as significantly associated with the outcome variable.

Results: The prevalence of respiratory symptoms among mothers of under-five years-old children in this study was 46.1\%. Education (vocational training compared to cannot read and write) (adjusted odd ratio (AOR) $=0.26$ at $95 \%$ confidence interval (Cl): 0.08-0.82), working in dusty environment ( $\mathrm{AOR}=2.90$ at $95 \% \mathrm{Cl}$ : 1.39-6.08), wood fire use $(A O R=0.37$ at $95 \% \mathrm{Cl}: 0.16-0.85)$, living in mud- and wood-walled houses ( $\mathrm{AOR}=0.53$ at $\mathrm{Cl}: 0.32-0.89)$, recent house painting ( $A O R=1.95$ at $95 \% \mathrm{Cl}: 1.03-3.69)$, new carpet $(A O R=2.02$ at $95 \% \mathrm{Cl}: 1.08-3.77)$, pesticide use $(A O R=1.71$ at $95 \% \mathrm{Cl}: 1.03-2.84)$, damp stain $(A O R=2.45$ at $95 \% \mathrm{Cl}: 1.04-5.75)$, spending longer time in house for 6

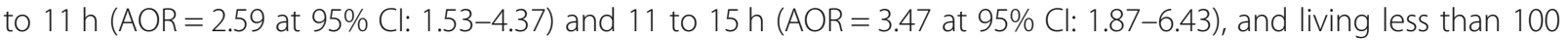
$\mathrm{m}$ from unpaved roads/streets ( $\mathrm{AOR}=4.35$ at $95 \% \mathrm{Cl}$ : 2.64-7.18) were significantly associated with respiratory symptoms among mothers of under-five years-old children.

Conclusion: Respiratory symptoms were common among mothers who have under five-years-old children. Air quality improvement, fuel selection, and residential planning will help to reduce respiratory symptoms.

Keywords: Children, Mothers, Household air pollution, Respiratory symptoms, Ethiopia

\footnotetext{
*Correspondence: jemberazanaw21@gmail.com

'Department of Environmental and Occupational Health and Safety, Institute of Public Health, College of Medicine and Health Sciences, University of Gondar, Gondar, Ethiopia

Full list of author information is available at the end of the article
}

(c) The Author(s). 2020 Open Access This article is licensed under a Creative Commons Attribution 4.0 International License, which permits use, sharing, adaptation, distribution and reproduction in any medium or format, as long as you give appropriate credit to the original author(s) and the source, provide a link to the Creative Commons licence, and indicate if changes were made. The images or other third party material in this article are included in the article's Creative Commons licence, unless indicated otherwise in a credit line to the material. If material is not included in the article's Creative Commons licence and your intended use is not permitted by statutory regulation or exceeds the permitted use, you will need to obtain permission directly from the copyright holder. To view a copy of this licence, visit http://creativecommons.org/licenses/by/4.0/. The Creative Commons Public Domain Dedication waiver (http://creativecommons.org/publicdomain/zero/1.0/) applies to the data made available in this article, unless otherwise stated in a credit line to the data. 


\section{Background}

Poor air quality of the household is likely to be the largest human health concern in modern society [1]. In households with poor ventilation (as it is common in many low- and middle-income countries), exposures experienced by household members, particularly women and young children who spend a large proportion of their time indoors, have been documented to be many times higher to develop respiratory symptoms [2]. An increasing number of evidences have associated housing quality with morbidity and mortality from infectious diseases, chronic illnesses, injuries, poor nutrition, and mental disorders [3, 4]. Each year, close to 4 million people die prematurely from illness attributable to household air pollution from inefficient cooking practices using polluting stoves along with solid fuels such as dung, wood, agricultural residues, coal, and kerosene. Among these 4 million deaths, $27 \%$ are due to pneumonia, $18 \%$ from stroke, $27 \%$ from ischemic heart disease, $20 \%$ from chronic obstructive pulmonary disease (COPD), and $8 \%$ from lung cancer [5]. The magnitude of respiratory symptoms varies across countries. Evidence from a recent epidemiologic study conducted among adult residents in Guizhou province, China showed the prevalence of asthma-like symptoms, and asthma was $13.1 \%$ in winter [6]. The prevalence of respiratory symptoms among workers reported in Iran and Thailand varies from $15.5 \%$ [7] to $41 \%$ [8]. The selfreported respiratory symptom prevalence among women using traditional stoves in rural Honduras was 82\% [9]. The prevalence of self-reported respiratory symptoms among Ethiopian women was $41.8 \%$ [10]. A study was done in Debre Berhan, Ethiopia demonstrated that the prevalence of bronchial asthma among adult patients was $29.6 \%$ [11]. Another comparative study carried out among textile factory workers in the northwest, Ethiopia revealed that the prevalence of self-reported respiratory symptoms in the slum areas of Addis Ababa and four rural kebeles of Butajira was 47.8\% [12].

Poor housing conditions are associated with a wide range of health problems, including respiratory infections, asthma, lead poisoning, injuries, and mental health. It has a multitude of adverse health consequences on a woman as well. For instance, exposure to air pollutants during pregnancy can potentially impede fetal development and cause several ill birth outcomes such as intrauterine growth retardation, prematurity, abortion, low birth weight, congenital anomalies, and, in cases that are more severe, intrauterine or perinatal death $[3,13]$.

Among the diverse environmental concerns facing lowand middle-income countries including Ethiopia, housing is the most fundamental one. Most urban settings in lowand middle-income countries were not designed to handle millions of people which directly impact the availability and affordability of housing, forcing millions to live in substandard dwellings with poor housing quality [14]. Poor household air quality and housing, as well as crowding, are still typical basic problems of growing settlements and megacities, most of which are located in low- and middle-income countries [15].

However, in low- and middle-income countries, there are many relevant housing and health challenges still to be averted. Earlier studies have identified that different factors have been correlated with respiratory symptoms among mothers who have under five-year-old children. For instance: second-hand tobacco smoke, involvement in the charcoal production business, weaving, annual mean concentrations of $\mathrm{NO}_{2}$, total suspended particulates, particulates of less than $10 \mu \mathrm{m}$ in aerodynamic diameter (PM10), ventilation, spinning, involvement in burning grass/field were significantly associated with respiratory symptoms [12, 16-18].

Evidences generated from this study would enable policymakers and program managers, administrators, Zonal health bureau, and other related stakeholders who work on this issue to understand the burden of the problem and its possible negative consequences which in turn direct them to a way of taking prompt actions and measures to alleviate the problem. The main objective of this study is to assess acute respiratory symptoms and its associated factors among mothers who have under fiveyear-old children in Gondar city, northwest Ethiopia.

\section{Methods and materials \\ Study design, period, and area}

A community-based cross-sectional study was conducted from February 15, 2019 to June 20, 2019 in Gondar city, northwest Ethiopia. The city is located in Central Gondar Zone, Amhara Regional State of Ethiopia and is $748 \mathrm{~km}$ far from Addis Ababa, the capital city of Ethiopia. It is about $180 \mathrm{~km}$ from Bahir Dar city, the capital of Amhara Regional State. The city has an latitude of $12^{\circ} 36^{\prime} \mathrm{N} 37^{\circ} 28^{\prime} \mathrm{E}$ and longitude of $12.60^{\circ} \mathrm{N} 37.467^{\circ} \mathrm{E}$ with an elevation of 2133 $\mathrm{m}$ above sea level and is divided into 12 administrative areas (sub-cities), which consists of 22 kebeles (the smallest administrative units in Ethiopia) (Fig. 1). Gondar is among one of the ancient and largely populated cities in the country. It has an estimated total population of 324,000 with about 23,929 mothers of under-five years-old children.

\section{Sample size calculation and sampling procedure}

The sample size was determined by using a single population proportion formula considering the following assumptions: $p=50 \%$ proportion of mothers with respiratory symptoms (there was no previous study in 


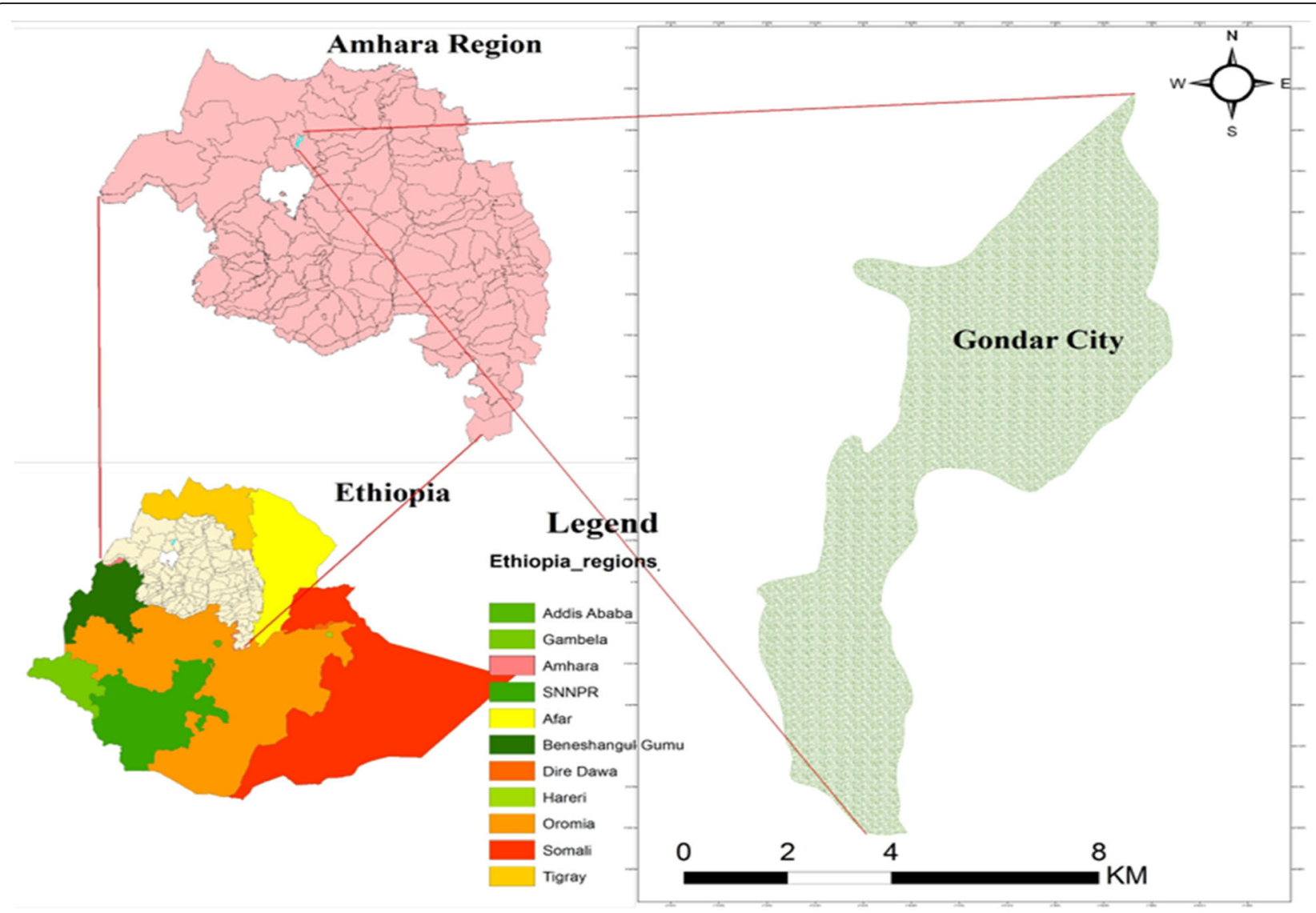

Fig. 1 Map of study area

the study area at the study period), 95\% confidence interval, $5 \%$ margin of error $(d)$ and design effect 2

$$
n=\frac{\left(Z_{\frac{\alpha}{2}}\right)^{2} \times p(1-p)}{d^{2}} \quad n=\frac{(1.96)^{2} \times 0.5(1-0.5)}{(0.05)^{2}}=384
$$

By taking $5 \%$ of the non-response rate, then the total sample size was 806 .

Multi-stage sampling technique was used as an assumption of being a heterogeneous population in the 12 administrative areas of the cities. Fifty percent of total sub-cities were selected through lottery method from the 12 administrative areas and all eligible study participants in the selected sub-cities were included in the study (Fig. 2).

\section{Data collection tools and procedures}

Through a face-to-face interview at the participants' home, data were collected using a pretested semistructured questionnaire (Additional file 1). The questionnaire was pre-tested to check the response, language clarity, and appropriateness at Azezo Dimaza sub-city (outside of the study area) with $5 \%$ of the total sample size (on 41 women). Based on the findings from the pre-test, modification and arrangement of questions was done. The outcome variable, i.e. respiratory symptoms (such as cough, shortness of breathing, wheezing, chest tightness, phlegm, and blocked or running nose); the explanatory variables such as sociodemographic factors (age of mothers, average monthly income, mother and spouse educational level, etc.) and household air pollutants (such as type fuels for cooking, types of fuel for heating, pesticide application, contact with farm animals (e.g., cattle, pigs, goats, sheep or poultry), smoke cigarettes (mothers/spouse), cockroach infestation in the household, painting/staining done in the last 6 months in households $(\mathrm{HH})$, new carpet, drapes or other textiles in the last 6 months, and using of air fresheners, etc.); and house characteristics such as floor construction materials, wall surface water-based paint, ceiling surface, damp stains, visible mold, normal cooking done, open doors during cooking, open windows during cooking, and time spent indoors on an average day were included in the questionnaires.

The questionnaire was first prepared in English and then translated to Amharic (local language) and back to English to maintain consistency of the tool. Six diploma 


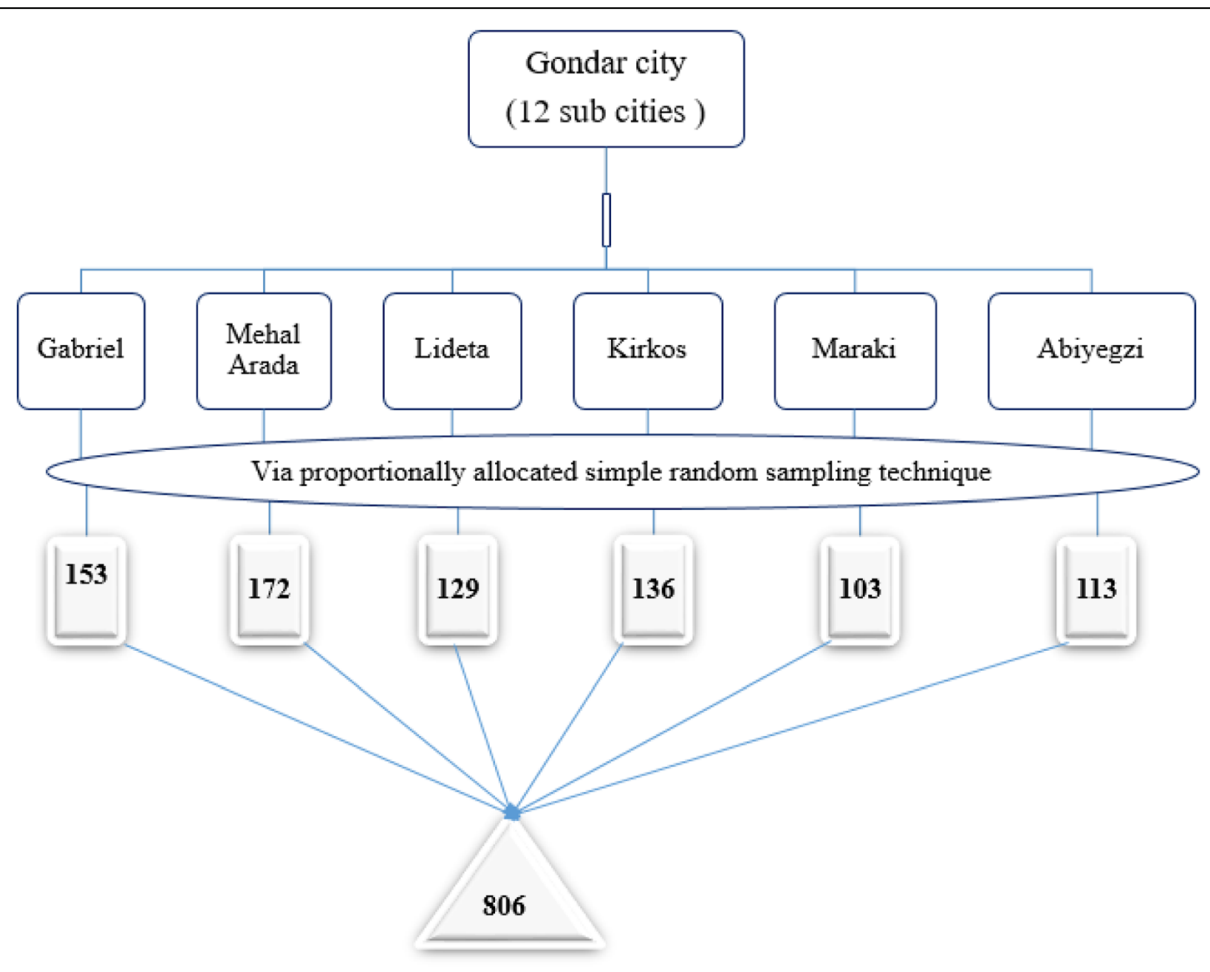

Fig. 2 A flow chart of the sampling procedures for selection of study participants in Gondar city, northwest Ethiopia 2019

nurses for data collection and one BSc nurse for supervision were involved after a two-day training.

\section{Operational definitions}

The outcome variable of this study was respiratory symptoms. Respiratory symptoms were defined as whether mothers had been suffering from cough, shortness of breathing, wheezing, chest tightness, phlegm, and blocked or running nose in the past 12 months [19, 20]. Mothers who have experienced at least one of the abovementioned symptoms were considered as having respiratory symptoms.

\section{Data processing and analysis}

Data were first checked manually for completeness and then coded and entered into Epi Info version 7.1.2.0. Then the data were exported to Stata 14.00 for data checking, cleaning, and analysis. Descriptive statistics were performed to describe the study population in relation to dependent and independent variables. Model fitness was checked with the assumptions of the Hosmer and Lemeshow test. Bivariable and multivariable logistic regressions were computed to identify the presence and strength of association. Variables with a $p$ value $<0.2$ during the bivariable binary logistic regression analysis were included in the multivariable binary logistic regression analysis. Odds ratio with 95\% CI was computed and variables having a $p$ value less than 0.05 in the multivariable binary logistic regression model were considered significantly associated with the dependent variable. Variance inflation factor was done to test multicollinearity (Additional file 2). To report this study Strengthening the Reporting of Observational Studies in Epidemiology (STROBE) guideline was used (Additional file 3).

\section{Result}

Sociodemographic characteristic of the study participants A total of 806 study participants were aimed in this study. Of this, 792 participants were enrolled with a response rate of $98.26 \%$. Two hundred twenty-seven (28.65\%) mothers were in the age category of 18-25 years whereas one hundred eighty-two (22.98\%) were in the class of above 33 years. The majority $(77.02 \%)$ of study participants were Orthodox Christian in religion followed by Muslims (17.68\%). Two thirds of mothers (67.98\%) were housewives (Table 1).

\section{Household air pollution and housing characteristics}

Three- fifth $(60.48 \%)$ and one- third (34.47\%) of the study participants used charcoal and electricity for cooking food, respectively. Nearly half $(47.85 \%)$ of the households were infested by cockroaches. Of the study participants, 250 (31.57\%) spend 6 to $11 \mathrm{~h}$ in their house/home, while 198 (25\%) mothers spend their time in the household for about $<6 \mathrm{~h}$. Above half $(55.56 \%)$ of the study participants used 
Table 1 Sociodemographic characteristics of study participants in Gondar city, northwest Ethiopia, 2019

\begin{tabular}{|c|c|c|}
\hline Variables & Frequency $(n=792)$ & Percent (\%) \\
\hline \multicolumn{3}{|c|}{ Education level of mothers $(n=778)$} \\
\hline Unable to read and write & 121 & 15.55 \\
\hline Read and write & 90 & 11.57 \\
\hline Primary & 100 & 12.85 \\
\hline Secondary & 253 & 32.52 \\
\hline Graduate from vocational & 30 & 3.86 \\
\hline Diploma and above & 184 & 23.65 \\
\hline \multicolumn{3}{|l|}{ Age of mothers } \\
\hline $18-25$ years & 227 & 28.66 \\
\hline 26-28 years & 206 & 26.01 \\
\hline 29-32 years & 177 & 22.35 \\
\hline$\geq 33$ years & 182 & 22.98 \\
\hline \multicolumn{3}{|c|}{ Median age of mothers $28 \pm 5.86$ (SD) } \\
\hline \multicolumn{3}{|l|}{ Religion } \\
\hline Orthodox & 610 & 77.02 \\
\hline Muslim & 140 & 17.68 \\
\hline Others* & 42 & 5.30 \\
\hline \multicolumn{3}{|l|}{ Mother's occupation $(n=784)$} \\
\hline Housewife & 533 & 67.98 \\
\hline Farmer & 4 & 0.51 \\
\hline Student & 8 & 1.02 \\
\hline Private employee & 52 & 6.63 \\
\hline Government employee & 142 & 18.11 \\
\hline Merchant & 35 & 4.46 \\
\hline Others (specify) & 10 & 1.28 \\
\hline \multicolumn{3}{|l|}{ Occupation of spouse $(n=723)$} \\
\hline Farmer & 18 & 2.49 \\
\hline Student & 8 & 1.11 \\
\hline Private employee & 310 & 42.88 \\
\hline Government employee & 232 & 32.09 \\
\hline Merchant & 88 & 12.17 \\
\hline Others & 67 & 9.27 \\
\hline
\end{tabular}

* Protestants, Jewish

wood and coal for heating their house during humid conditions and $43.06 \%$ did not use any fuel for heating (Table 2).

\section{Prevalence of respiratory symptoms among mothers}

The prevalence of respiratory symptoms among mothers in Gondar city was $46.1 \%$ at 95\% [CI: $42.6 \%-49.7 \%$ ]. Commonly reported respiratory symptoms were runny nose, shortness of breath, and phlegm with a magnitude of $32.07 \%, 15.03 \%$, and $12.63 \%$, respectively. The lowest recorded respiratory symptom among mothers was chest tightness which accounted for $4.42 \%$ (Fig. 3).
Factors associated with respiratory symptoms of mothers On multivariable analysis, educational level of mothers; poor (dusty or smelly) working environment; frequent use of fuel for cooking and heating; painting/staining done in the last 6 months $\mathrm{HH}$; new carpet, drapes, or other textiles in $\mathrm{HH}$; pesticide use at $\mathrm{HH}$; floor construction materials; damp stains; length/duration of time spending in the house/ indoors; and living less than 100 $\mathrm{m}$ (unpaved roads/streets) were significantly associated with mothers' respiratory symptoms.

Study participants who graduated from vocational training were $74 \%$ less likely to encounter respiratory symptoms compared to those who cannot or are unable to read and write ( $\mathrm{AOR}=0.26$ at $95 \% \mathrm{CI}: 0.08-0.82$ ). Mothers who work in a poor (dusty or smelly) environment were 2.90 times more likely to develop respiratory symptoms than their counterparts (AOR $=2.90$ at $95 \%$ CI: $1.39-6.08)$.

Study participants who used an open fire for cooking were $63 \%$ less likely to develop respiratory symptoms compared with those who used charcoal (AOR $=0.37$ at $95 \%$ CI: 0.16-0.85). Mothers who live in painted $\mathrm{HH}$ were 1.95 times more likely to develop respiratory symptoms than their counterparts (AOR $=1.95$ at $95 \%$ CI: $1.03-3.69$ ).

Those respondents who use new carpets in $\mathrm{HH}$ were 2.02 times more likely to develop respiratory symptoms compared with their counterparts (AOR $=2.02$ at 95\% CI: 1.08-3.77). Mothers who used pesticides in $\mathrm{HH}$ were 1.71 times at higher risk of experiencing respiratory symptoms than those who did not use $(\mathrm{AOR}=1.71$ at 95\% CI: 1.03-2.84).

Those respondents, whose house floor was constructed from brick and concrete were $47 \%$ times less likely to be a victim of respiratory symptoms when compared with those who constructed their house floor from mud and wood (AOR $=0.53$ at CI: $0.32-0.89$ ). The odds ratio of having respiratory symptoms among mothers whose households had damp stains was 2.45 compared to their counterparts (AOR $=2.45$ at $95 \% \mathrm{CI}: 1.04-5.75)$.

Study participants who spend much of their time (6 to $11 \mathrm{~h}$ ) indoors were 2.59 times highly likely to face respiratory symptoms compared with those who spent a few hours $(<6 \mathrm{~h})$ indoors (AOR $=2.59$ at $95 \% \mathrm{CI}$ : 1.53 4.37) and the risk increases among respondents who spent 11 to $15 \mathrm{~h}$ of their time in the house/indoors (AOR $=3.47$ at $95 \%$ CI: $1.87-6.43)$.

Study participants who live less than $100 \mathrm{~m}$ (unpaved roads/streets) were 4.35 times more likely to experience respiratory symptoms than their counterparts $(\mathrm{AOR}=$ 4.35 at $95 \%$ CI: $2.64-7.18$ ) (Table 3).

\section{Discussion}

The overall prevalence of respiratory symptoms in the current study was $46.1 \%$ at $95 \%$ [CI: $42.6 \%-49.7 \%$ ]. This 
Table 2 Household air pollution and housing characteristics of the study participants in Gondar city, northwest Ethiopia, 2019 \begin{tabular}{lll}
\hline Variables & Frequency $(n=792)$ & Percent $(\%)$ \\
\hline
\end{tabular} Types of fuel usually used for cooking

$\begin{array}{ll}\text { Charcoal } & 479 \\ \text { Electricity } & 273 \\ \text { Open fires } & 40\end{array}$

Open fires

40

Types of fuel usually used for heating

$\begin{array}{lll}\text { None } & 341 & 43.06 \\ \text { Wood, coal } & 440 & 55.56 \\ \text { Electricity } & 11 & 1.39\end{array}$

Contact with farm animals (e.g., cattle, pigs, goats, sheep, or poultry)

No

745

Yes

47

Smoke cigarettes (mothers/guardians)

$$
\begin{array}{ll}
\text { No } & 768 \\
\text { Yes } & 24
\end{array}
$$

Cockroach infestation in household

$\begin{array}{ll}\text { No } & 413 \\ \text { Yes } & 379\end{array}$

Painting/staining done in the last 6 months $\mathrm{HH}$

$\begin{array}{ll}\text { No } & 682 \\ \text { Yes } & 110\end{array}$

New carpet, drapes, or other textiles in the last 6 months

No

Yes

110

Using air freshener

No

Yes

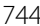

48

Presence of a kitchen exhaust fan

$$
\begin{array}{ll}
\text { No } & 752 \\
\text { Yes } & 40
\end{array}
$$

A pesticide application

$\begin{array}{ll}\text { No } & 635 \\ \text { Yes } & 157\end{array}$

Floor construction materials

$\begin{array}{ll}\text { Wood and mud } & 542 \\ \text { Brick and concrete } & 250\end{array}$

Wall surface water-based paint

No

Yes

174

Ceiling surface $(n=749)$

Wooden

Painted

Cement

42
60.48

94.07

Table 2 Household air pollution and housing characteristics of the study participants in Gondar city, northwest Ethiopia, 2019 (Continued)

\begin{tabular}{lll}
\hline Variables & Frequency $(n=792)$ & Percent (\%) \\
\hline No & 729 & 92.05 \\
Yes & 63 & 7.95 \\
Visible mold & & \\
No & 725 & 91.54 \\
Yes & 67 & 8.46 \\
Place of cooking $(n=775)$ & & \\
Inside & 461 & 59.48 \\
Outside & 314 & 40.52 \\
Open doors during cooking & & \\
No & 439 & 64.56 \\
Yes & 241 & 35.44 \\
Open windows during cooking & & 68.34 \\
No & 462 & 31.66 \\
Yes & 214
\end{tabular}

Average length/duration of time spend in house/home/indoor on a day

$\begin{array}{lll}<6 \mathrm{~h} & 198 & 25.00 \\ 6 \text { to } 11 \mathrm{~h} & 250 & 31.57 \\ 11 \text { to } 15 \mathrm{~h} & 165 & 20.83 \\ >15 \mathrm{~h} & 179 & 22.60\end{array}$

Presence of garage less than $100 \mathrm{~m}$ from household

$\begin{array}{lll}\text { No } & 746 & 94.19 \\ \text { Yes } & 46 & 5.81\end{array}$

Frequency of trucks passing through the street where you live, on weekdays

93.94

6.06

$\begin{array}{lll}\text { Never } & 397 & 50.13 \\ \text { Seldom } & 254 & 32.07 \\ \text { Frequently } & 93 & 11.74 \\ \text { Almost the whole day } & 48 & 6.06\end{array}$

Living less than $100 \mathrm{~m}$ heavy traffic

$\begin{array}{lll}\text { No } & 630 & 79.55 \\ \text { Yes } & 162 & 20.45\end{array}$

Living less than $100 \mathrm{~m}$ (unpaved roads/streets)

$\begin{array}{lll}\text { No } & 598 & 75.51\end{array}$

Exposure to animal allergens in early childhood

$\begin{array}{lll}\text { No } & 754 & 95.20 \\ \text { Yes } & 38 & 4.80\end{array}$

Exposure to animal allergens in the present time

No $\quad 747$

94.32

17.49

5.61

Damp stains 


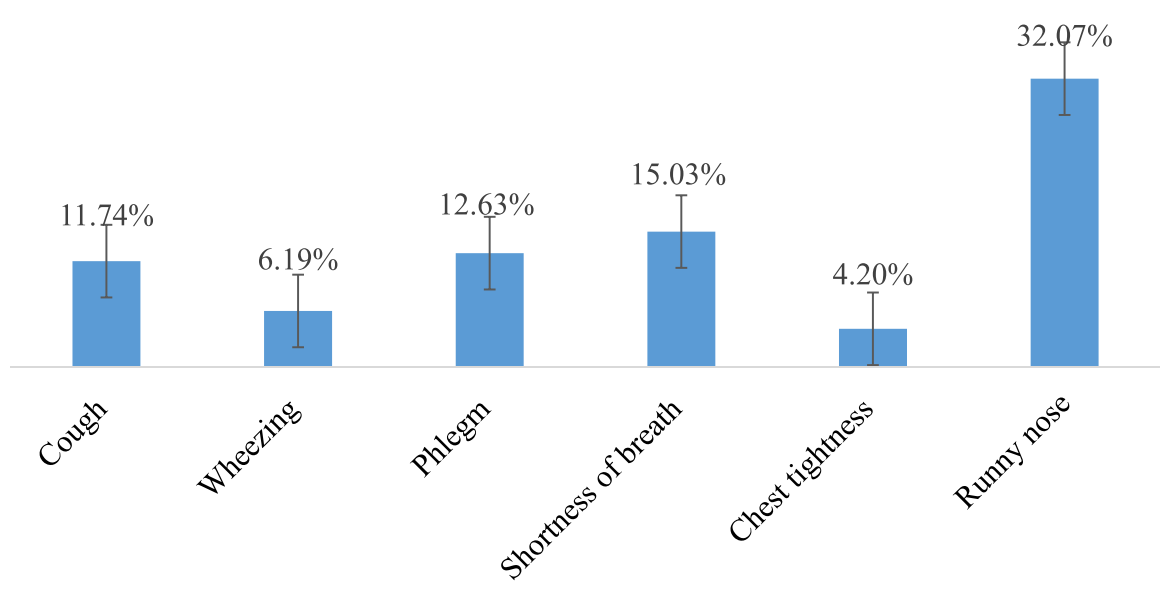

Fig. 3 Prevalence of respiratory symptoms among mothers in Gondar city, northwest Ethiopia, 2019

result is lower than self-reported respiratory symptoms from rural Honduras [9] and South India [21]. However, the prevalence was higher than respiratory involvement among women exposed to the smoke of traditional biomass and gas fuel in Bangladesh [22], respiratory symptoms in Indian women [23], and women in West Sierra Leone [24]. The prevalence is closer to an earlier report from Ethiopia [10]. The differences in the proportion of self-reported respiratory symptoms may be attributed to a difference in the level of socioeconomic status, housing conditions, fuel type used, measurement difference, and study period.

Educational status was associated with mothers' respiratory symptoms. Mothers who attended technical and vocational training were less likely to develop respiratory symptoms as compared to those who cannot read and write. Lower educational status was reported as a risk factor for asthma and respiratory symptoms in many cross-sectional studies [25-28] and a cohort study [29]. The reason for the association of educational status and respiratory symptoms might be due to the fact that educational status is among the most common indicators used for measurement of socioeconomic status [30]. Educational level was associated with income and the capacity to buy clean fuel in a previous study [31] and lower educational level was more strongly associated with biofuel use which results in a higher risk of respiratory infection $[32,33]$.

In our analysis, the adjusted odds ratio of respiratory symptom was 2.9-folds among mothers working in dusty and smelly environment compared to those who reported working in a clean environment. The effects of occupational dust exposure on the reduction of pulmonary function and aggravation of respiratory symptoms have long been confirmed [34-36]. Exposure to dust results in a reduction of lung function due to pulmonary obstruction, and dust particles serve as a vehicle for disease-causing microorganisms [35, 36]. The chemical composition of dust may also be responsible for respiratory symptoms $[37,38]$.

Fuel type usually used for cooking is another factor associated with respiratory symptoms in this study. The use of open firewood was protective against respiratory symptoms as compared to charcoal use in the current study. This is against reports from several earlier evidence $[39,40]$, whereby charcoal was better than an open fire and firewood in terms of a respiratory outcome as coal produces less particulate matter than open fire and wood. Even though charcoal is often considered as a clean fuel compared to the other biomass fuels, such as firewood, animal dung, crop residues [41, 42], Das et al. [39] and Sana et al. [43], consistent to the present study, found positive associations between respiratory symptoms and firewood compared to charcoal. Sana et al. [43] reported that charcoal is not easy to set on fire, and the cooks usually use fire starters such as plastic bags, tire rubber cut or inner tire tubes, drainage oil, paper, agricultural waste, petrol coke powder, twigs, and dry herbs. Plastic especially releases toxic gases like dioxins, furans, mercury, and polychlorinated biphenyls, as well as some additives as phthalates and brominated flame retardants which pose respiratory health risks [44].

Mothers who reside at houses painted in the past 6 months prior to the study were at higher odds of respiratory symptoms. Indoor paints may emit harmful chemicals that result in respiratory irritation [45]. Recent indoor painting was reported as one of the risk factors to respiratory symptoms in several previous studies [45-50].

Study participants who live in houses and reported pesticide use were at higher risk of respiratory symptoms. This was in line with an earlier study [51]. The potential plausibility of the observed association can be explained by the toxicological and clinical nature of the 
Table 3 Factors associated with mothers' respiratory symptoms in Gondar city northwest Ethiopia, 2019

\begin{tabular}{|c|c|c|c|c|}
\hline \multirow[t]{2}{*}{ Variables } & \multicolumn{2}{|c|}{ Respiratory symptom } & \multirow[t]{2}{*}{ COR 95\% Cl } & \multirow[t]{2}{*}{ AOR 95\% Cl } \\
\hline & Absent & Present & & \\
\hline \multicolumn{5}{|l|}{ Educational level of mothers } \\
\hline Unable to read and write & 56 & 65 & 1 & 1 \\
\hline Read and write & 32 & 58 & $1.56(0.89-2.73)$ & $1.24(0.63-2.49)$ \\
\hline Primary & 58 & 42 & $0.62(0.37-1.06)$ & $0.69(0.35-1.37)$ \\
\hline Secondary & 141 & 112 & $068(0.44-1.06)$ & $0.57(0.32-1.02)$ \\
\hline Graduate from vocational training & 22 & 8 & $0.31(0.13-0.75)$ & $0.26(0.08-0.82)^{*}$ \\
\hline Diploma and above & 110 & 74 & $0.51(0.36-0.92)$ & $0.55(0.29-1.05)$ \\
\hline \multicolumn{5}{|c|}{ Poor (dusty or smelly) working environment } \\
\hline No & 403 & 319 & 1 & 1 \\
\hline Yes & 24 & 46 & $2.44(1.45-4.05)$ & $2.90(1.39-6.08)^{*}$ \\
\hline \multicolumn{5}{|l|}{ Fuel type usually used for cooking } \\
\hline Charcoal & 237 & 242 & 1 & 1 \\
\hline Electricity & 164 & 109 & $0.65(0.48-0.88)$ & $0.73(0.45-1.16)$ \\
\hline Open fires & 26 & 14 & $0.53(0.26-1.03)$ & $0.37(0.16-0.85)^{*}$ \\
\hline \multicolumn{5}{|l|}{ Fuel type usually used for heating } \\
\hline None & 222 & 119 & 1 & 1 \\
\hline Wood, coal & 201 & 239 & $2.22(1.66-2.97)$ & $1.17(0.76-1.81)$ \\
\hline Electricity & 4 & 7 & $3.26(0.94-11.37)$ & $1.77(0.42-7.40)$ \\
\hline \multicolumn{5}{|c|}{ Mother contact with farm animals (e.g., cattle, sheep, or poultry) } \\
\hline No & 413 & 332 & 1 & 1 \\
\hline Yes & 14 & 33 & $2.93(1.54-5.56)$ & $1.41(0.65-3.07)$ \\
\hline \multicolumn{5}{|c|}{ Painting/staining been done in the last 6 months $\mathrm{HH}$} \\
\hline No & 390 & 292 & 1 & 1 \\
\hline Yes & 37 & 73 & $2.63(1.73-4.02)$ & $1.95(1.03-3.69)^{*}$ \\
\hline \multicolumn{5}{|c|}{ New carpet, drapes, or other textiles in $\mathrm{HH}$} \\
\hline No & 39 & 288 & 1 & 1 \\
\hline Yes & 33 & 77 & $3.19(2.07-4.93)$ & $2.02(1.08-3.77)^{*}$ \\
\hline \multicolumn{5}{|l|}{ Pesticide use at $\mathrm{HH}$} \\
\hline No & 366 & 269 & 1 & 1 \\
\hline Yes & 61 & 96 & $2.14(1.49-3.06)$ & $1.71(1.03-2.84)^{*}$ \\
\hline \multicolumn{5}{|l|}{ Floor construction materials } \\
\hline Wood and mud & 263 & 279 & 1 & 1 \\
\hline Brick and concrete & 164 & 86 & $0.49(0.36-0.67)$ & $0.53(0.32-0.89)^{*}$ \\
\hline \multicolumn{5}{|l|}{ Wall surface water-based paint } \\
\hline No & 312 & 306 & 1 & 1 \\
\hline Yes & 115 & 59 & $0.52(0.37-0.74)$ & $0.81(0.46-1.41)$ \\
\hline \multicolumn{5}{|l|}{ Damp stains } \\
\hline No & 402 & 327 & 1 & 1 \\
\hline Yes & 25 & 38 & $1.86(1.10-3.16)$ & $2.45(1.04-5.75)^{*}$ \\
\hline \multicolumn{5}{|l|}{ Open windows during cooking } \\
\hline No & 207 & 255 & 1 & 1 \\
\hline Yes & 138 & 76 & $0.44(0.32-0.62)$ & $0.71(0.45-1.13)$ \\
\hline
\end{tabular}

Duration/length of time spending indoors 
Table 3 Factors associated with mothers' respiratory symptoms in Gondar city northwest Ethiopia, 2019 (Continued)

\begin{tabular}{|c|c|c|c|c|}
\hline \multirow[t]{2}{*}{ Variables } & \multicolumn{2}{|c|}{ Respiratory symptom } & \multirow[t]{2}{*}{ COR 95\% Cl } & \multirow[t]{2}{*}{ AOR $95 \% \mathrm{Cl}$} \\
\hline & Absent & Present & & \\
\hline$<6 \mathrm{~h}$ & 127 & 71 & 1 & 1 \\
\hline 6 to $11 \mathrm{~h}$ & 121 & 129 & $1.90(1.30-2.79)$ & $2.59(1.53-4.37)^{* *}$ \\
\hline 11 to $15 \mathrm{~h}$ & 65 & 100 & $2.75(1.79-4.21)$ & $3.47(1.87-6.43)^{* *}$ \\
\hline$>15 \mathrm{~h}$ & 114 & 65 & $1.02(0.67-1.55)$ & 1.65(0.83-3.29) \\
\hline \multicolumn{5}{|c|}{ Presence of attached garage living less than $100 \mathrm{~m} \mathrm{HH}$} \\
\hline No & 414 & 332 & 1 & 1 \\
\hline Yes & 13 & 33 & $3.16(1.64-6.11)$ & $1.91(0.85-4.25)$ \\
\hline \multicolumn{5}{|c|}{ Trucks pass through the street where you live, on weekdays? } \\
\hline Never & 255 & 142 & 1 & 1 \\
\hline Seldom & 103 & 151 & $2.63(1.90-3.63)$ & $1.52(0.94-2.44)$ \\
\hline Frequently & 43 & 50 & $2.08(1.32-.29)$ & $1.01(1.87-6.43)$ \\
\hline Almost whole day & 26 & 22 & $1.51(0.83-2.77)$ & $0.66(0.83-3.29)$ \\
\hline \multicolumn{5}{|c|}{ Living less than $100 \mathrm{~m}$ from heavy traffic } \\
\hline No & 366 & 264 & 1 & 1 \\
\hline Yes & 61 & 101 & $2.29(1.60-3.27)$ & $1.25(0.73-2.15)$ \\
\hline \multicolumn{5}{|c|}{ Living less than $100 \mathrm{~m}$ (unpaved roads/streets) } \\
\hline No & 382 & 216 & 1 & 1 \\
\hline Yes & 45 & 149 & $5.85(4.03-8.50)$ & $4.35(2.64-7.18)^{* *}$ \\
\hline \multicolumn{5}{|c|}{ Exposure to animal allergens in early childhood } \\
\hline No & 415 & 339 & 1 & 1 \\
\hline Yes & 12 & 26 & $2.65(1.32-5.33)$ & $0.51(0.13-1.98)$ \\
\hline \multicolumn{5}{|c|}{ Exposure to animal allergens in the present time } \\
\hline No & 411 & 336 & 1 & 1 \\
\hline Yes & 16 & 29 & $2.21(1.18-4.15)$ & $1.19(0.36-3.85)$ \\
\hline
\end{tabular}

$1=$ Reference group

* Significant at $p<0.05,{ }^{* *}$ Significant at $p<0.001$

pesticides. Most pesticides have low molecular weight, which enables them to induce immediate humoral immune-mediated allergic reactions [52, 53]. Exposure to organo chlorines at high concentrations may result in mucus hypersecretion and airway smooth muscle contraction leading to breathlessness, wheezing, and cough [54]. It favors the T-helper cell (Th) type 2 immunophenotype associated with asthma and allergy [55].

Living within $100 \mathrm{~m}$ of the unpaved road was a risk factor for respiratory symptoms in the sense of exposure to outdoor air pollutants. There is well-established evidence that exposure to air pollution results in a higher risk of a respiratory infection such as pneumonia [56-61].

The presence of damp stain was another risk factor affecting respiratory symptoms, and this is not surprising as mold growth is favored in damp conditions [62, 63]. In the current study, the presence of new carpet in the house was a risk factor for respiratory symptoms among women. The presence of new furniture such as carpet has been associated with respiratory illnesses in several earlier studies [64, 65]. Carpets harbor house dust and thereby respiratory illness-causing pathogens [66].

Respondents who spend much of their time (6 to 11) hours and (11 to 15) hours indoors had 2.59 and 3.47 high odds of facing respiratory symptoms compared with those who spent a few hours $(<6 \mathrm{~h})$, respectively. Even though the current study has shown spending a long time in indoor environments is a risk for acute respiratory symptoms, this is not consistent with spending more than $15 \mathrm{~h}$ indoors. Perhaps, those who spend their time indoors may have kept the house and ventilation and their surrounding environments clean.

Lastly, study participants who live in houses made up of wood and mud were at higher risk of respiratory symptoms.

\section{Limitations of the study}

Although large sample size and simple random sampling employed in this study which helps for greater generalizability, lack of measurements, i.e., pulmonary 
function test and inherent nature of the cross-sectional study which fails to show cause-effect relationships were the limitations of this study. In addition, recall and social desirability biases might be high in such types of selfreported cross-sectional studies.

\section{Conclusion}

The overall prevalence of respiratory symptoms was relatively high among mothers who have under fiveyears-old children. Several modifiable factors such as educational level, working in a dusty environment, fuel type used for cooking, recent house painting, presence of new carpet and damp stain, pesticide use, living in mud- and wood-walled houses, spending longer time indoors, and living near unpaved roads/streets were found to be significantly associated with respiratory symptoms among mothers. Thus, we recommend policymakers and implementers to engage in household air quality improvements, fuel selection, and residential house planning to help mothers protect from respiratory symptoms.

\section{Supplementary information}

Supplementary information accompanies this paper at https://doi.org/10. 1186/s12199-020-00859-4.

Additional file 1. Questionaire.

Additional file 2. VIF result.

Additional file $\mathbf{3}$. STROBE checklist.

\section{Abbreviations}

AOR: Adjusted odds ratio; Cl: Confidence interval; COR: Crude odds ratio; $\mathrm{HH}$ : Household

\section{Acknowledgments}

We are highly indebted to Gondar City Health Office for permitting to conduct the study and providing the necessary preliminary information while conducting this study. We would also like to extend our appreciation to the study participants, supervisors, and data collectors.

\section{Authors' contributions}

All stated authors ZA, ZNA, JA, AAT, and HD are involved in the study from the inception to design, acquisition of data, analysis and interpretation, and drafting of the manuscript. The authors read and approved the final manuscript.

\section{Funding}

The authors received no specific funding for this work.

\section{Availability of data and materials}

The dataset analyzed during the current study are available from the corresponding author on reasonable request.

\section{Ethics approval and consent to participate}

The study was conducted after obtaining ethical clearance from the Institutional Review Board of University of Gondar with IRB number of ON/ PRCS/05/369. An official letter of cooperation was written to Gondar city administration. After a clear and detailed explanation of the purpose, risks, and benefits of the study, written informed consent was obtained from each of the mothers/study participants. We told mothers that participation was voluntary and that they can withdraw at any time if they are not comfortable during the interview. During data collection, mothers identified with clear acute respiratory infection were referred to the health institutions for appropriate treatment. Personal identifiers were not included in the written tool to ensure confidentiality.

\section{Consent for publication}

Not applicable.

\section{Competing interests}

The authors declare that they have no competing interests.

\section{Author details}

${ }^{1}$ Department of Environmental and Occupational Health and Safety, Institute of Public Health, College of Medicine and Health Sciences, University of Gondar, Gondar, Ethiopia. 'Department of Women's and Family Health, School of Midwifery, College of Medicine and Health Sciences, University of Gondar, Gondar, Ethiopia. ${ }^{3}$ Department of Epidemiology and Biostatistics, Institute of Public Health, College of Medicine and Health Sciences, University of Gondar, Gondar, Ethiopia.

Received: 25 March 2020 Accepted: 2 June 2020

Published online: 15 June 2020

\section{References}

1. Sussan TE, Ingole V, Kim J-H, McCormick S, Negherbon J, Fallica J, et al. Source of biomass cooking fuel determines pulmonary response to household air pollution. Am J Respir Cell Mol Biol. 2014;50(3):538-48.

2. Smith KR, Mehta $S$. The burden of disease from indoor air pollution in developing countries: comparison of estimates. Int J Hyg Environ Health. 2003;206(4-5):279-89.

3. Krieger J, Higgins DL. Housing and health: time again for public health action. Am J Public Health. 2002;92(5):758-68.

4. Li S, Xu J, Jiang Z, Luo Y, Yang Y, Yu J. Correlation between indoor air pollution and adult respiratory health in Zunyi City in Southwest China: situation in two different seasons. BMC Public Health. 2019;19(1):723.

5. WHO. Household air pollution and health. WHO Geneva, Switzerland; 2014.

6. Jie $Y$, Isa ZM, Jie $X$, Ismail NH. Asthma and asthma-related symptoms among adults of an acid rain-plagued city in Southwest China: prevalence and risk factors. Polish Journal of Environmental Studies. 2013;22(3).

7. Neghab M, Jabari Z, Shouroki FK. Functional disorders of the lung and symptoms of respiratory disease associated with occupational inhalation exposure to wood dust in Iran. Epidemiology and health. 2018;40.

8. Sripaiboonkij P, Phanprasit W, Jaakkola MS. Respiratory and skin effects of exposure to wood dust from the rubber tree Hevea brasiliensis. Occup Environ Med. 2009:66(7):442-7.

9. Young BN, Clark ML, Rajkumar S, Benka-Coker ML, Bachand A, Brook RD, et al. Exposure to household air pollution from biomass cookstoves and blood pressure among women in rural Honduras: a cross-sectional study. Indoor Air. 2019;29(1):130-42.

10. Tamire M, Addissie A, Kumie A, Husmark E, Skovbjerg S, Andersson R, et al. Respiratory symptoms and lung function among Ethiopian women in relation to household fuel use. Int J Environ Res Public Health. 2020;17(1):41.

11. Shine S, Muhamud S, Demelash A. Prevalence and associated factors of bronchial asthma among adult patients in Debre Berhan Referral Hospital, Ethiopia 2018: a cross-sectional study. BMC research notes. 2019;12(1):608.

12. Wami SD, Chercos DH, Dessie A, Gizaw Z, Getachew A, Hambisa T, et al. Cotton dust exposure and self-reported respiratory symptoms among textile factory workers in Northwest Ethiopia: a comparative cross-sectional study. Journal of Occupational Medicine and Toxicology. 2018;13(1):13.

13. Šrám RJ, Binková B, Dejmek J, Bobak M. Ambient air pollution and pregnancy outcomes: a review of the literature. Environ Health Perspect. 2005;113(4):375-82.

14. Lanrewaju AF. Urbanization, housing quality and environmental degeneration in Nigeria. Journal of Geography and Regional Planning. 2012; 5(16):422-9.

15. Bonnefoy $X$. Inadequate housing and health: an overview. Int J Environ Pollut. 2007;30(3-4):411-29.

16. Van Vliet ED, Kinney PL, Owusu-Agyei S, Schluger NW, Whyatt RM, Jack DW, et al. Current respiratory symptoms and risk factors in pregnant women cooking with biomass fuels in rural Ghana. Environ Int. 2019;124:533-40. 
17. Zemp E, Elsasser S, Schindler C, Kunzli N, Perruchoud AP, Domenighetti G, et al. Long-term ambient air pollution and respiratory symptoms in adults (SAPALDIA study). Am J Respir Crit Care Med. 1999;159(4):1257-66.

18. Segala C, Fauroux B, Just J, Pascual L, Grimfeld A, Neukirch F. Short-term effect of winter air pollution on respiratory health of asthmatic children in Paris. Eur Respir J. 1998;11(3):677-85.

19. Hasan M, Tasfina S, Haque SR, Saif-Ur-Rahman K, Khalequzzaman M, Bari W, et al. Association of biomass fuel smoke with respiratory symptoms among children under 5 years of age in urban areas: results from Bangladesh Urban Health Survey, 2013. Environ Health Prev Med. 2019;24(1):65.

20. Benefits Bridge United Concordia. 6 common respiratory disease symptoms 2019 [cited 2019 February, 08]. Available from: https://benefitsbridge. unitedconcordia.com/6-common-respiratory-disease-symptoms-to-beaware-of/.

21. Rumchev K, Zhao Y, Spickett J. Health risk assessment of indoor air quality, socioeconomic and house characteristics on respiratory health among women and children of Tirupur, South India. Int J Environ Res Public Health. 2017;14(4):429.

22. Alim MA, Sarker MAB, Selim S, Karim MR, Yoshida Y, Hamajima N Respiratory involvements among women exposed to the smoke of traditional biomass fuel and gas fuel in a district of Bangladesh. Environ Health Prev Med. 2014;19(2):126.

23. Behera D, Jindal SK. Respiratory symptoms in Indian women using domestic cooking fuels. Chest. 1991;100(2):385-8.

24. Taylor ET, Nakai S. Prevalence of acute respiratory infections in women and children in Western Sierra Leone due to smoke from wood and charcoal stoves. Int J Environ Res Public Health. 2012;9(6):2252-65.

25. Bakke PS, Hanoa R, Gulsvik A. Educational level and obstructive lung disease given smoking habits and occupational airborne exposure: a Norwegian community study. Am J Epidemiol. 1995;141(11):1080-8.

26. Prescott $E$, Lange $P$, Vestbo J. Socioeconomic status, lung function and admission to hospital for COPD: results from the Copenhagen City Heart Study. Eur Respir J. 1999;13(5):1109-14.

27. Lindström M, Jönsson E, Kotaniemi J, Lundbäck B. Smoking, respiratory symptoms, and diseases: a comparative study between northern Sweden and northern Finland: report from the FinEsS study. Chest. 2001;119(3):85261.

28. Beckett WS, Jacobs DR Jr, Yu X, Iribarren C, Williams OD. Asthma is associated with weight gain in females but not males, independent of physical activity. Am J Respir Crit Care Med. 2001;164(11):2045-50.

29. Eagan TM, Gulsvik A, Eide GE, Bakke PS. The effect of educational level on the incidence of asthma and respiratory symptoms. Respir Med. 2004;98(8): 730-6.

30. Liberatos $P$, Link BG, Kelsey JL. The measurement of social class in epidemiology. Epidemiol Rev. 1988;10(1):87-121.

31. Bildirici ME. Economic growth and biomass energy. Biomass Bioenergy. 2013:50:19-24

32. Parikh P, Kwami CS, Vivekanand V, Paritosh K, Lakhanpaul M. Linkages between respiratory symptoms in women and biofuel use: regional case study of Rajasthan, India. Int J Environ Res Public Health. 2019;16(19):3594.

33. Menghwani $V$, Zerriffi $H$, Dwivedi $P$, Marshall JD, Grieshop A, Bailis R. Determinants of cookstoves and fuel choice among rural households in India. EcoHealth. 2019:16(1):21-60.

34. Meo SA, Al-Drees AM, Al Masri AA, Al Rouq F, Azeem MA. Effect of duration of exposure to cement dust on respiratory function of non-smoking cement mill workers. Int J Environ Res Public Health. 2013;10(1):390-8.

35. Nagoda M, Okpapi J, Babashani M. Assessment of respiratory symptoms and lung function among textile workers at Kano Textile Mills, Kano, Nigeria. Niger J Clin Pract. 2012;15(4):373.

36. Zeleke ZK, Moen BE, Bråtveit M. Lung function reduction and chronic respiratory symptoms among workers in the cement industry: a follow up study. BMC pulmonary medicine. 2011;11(1):50.

37. Saini-Eidukat B, Triplett JW. Erionite and offretite from the Killdeer Mountains, Dunn County, North Dakota, USA. Am Mineral. 2014;99(1):8-15.

38. Barrett JE, Taylor KG, Hudson-Edwards KA, Charnock JM. Solid-phase speciation of $\mathrm{Pb}$ in urban road dust sediment: a XANES and EXAFS study. Environ Sci Technol. 2010;44(8):2940-6.

39. Das I, Jagger P, Yeatts K. Biomass cooking fuels and health outcomes for women in Malawi. Ecohealth. 2017;14(1):7-19.

40. Jetter J, Zhao Y, Smith KR, Khan B, Yelverton T, DeCarlo $P$, et al. Pollutant emissions and energy efficiency under controlled conditions for household biomass cookstoves and implications for metrics useful in setting international test standards. Environ Sci Technol. 2012;46(19):10827-34.

41. Fullerton DG, Suseno A, Semple S, Kalambo F, Malamba R, White S, et al. Wood smoke exposure, poverty and impaired lung function in Malawian adults. The International journal of tuberculosis and lung disease. 2011;15(3): 391-8.

42. Rehfuess E, Mehta S, Prüss-Üstün A. Assessing household solid fuel use: multiple implications for the Millennium Development Goals. Environ Health Perspect. 2006;114(3):373-8.

43. Sana A, Meda N, Badoum G, Kafando B, Bouland C. Primary cooking fuel choice and respiratory health outcomes among women in charge of household cooking in Ouagadougou, Burkina Faso: cross-sectional study. Int J Environ Res Public Health. 2019;16(6):1040.

44. Verma R, Vinoda K, Papireddy M, Gowda A. Toxic pollutants from plastic waste-a review. Procedia Environ Sci. 2016;35:701-8.

45. Wieslander G, Norbäck D, Björnsson E, Janson C, Boman G. Asthma and the indoor environment: the significance of emission of formaldehyde and volatile organic compounds from newly painted indoor surfaces. Int Arch Occup Environ Health. 1996:69(2):115-24.

46. Takaoka M, Suzuki K, Norbäck D. The home environment of junior high school students in Hyogo, Japan-associations with asthma, respiratory health and reported allergies. Indoor and Built Environment. 2016;25(1):8192.

47. Svanes C, Omenaas E, Norrman E, Jõgi R, Jensen E, Dahlman-Höglund A, et al. Prevalence and incidence of respiratory symptoms. Thorax. 2006;61: 221-5.

48. Takaoka M, Norback D. The home environment of Japanese female university students - association with respiratory health and allergy. Indoor and Built Environment. 2011;20(3):369-76.

49. Diez U, Rehwagen M, Rolle-Kampczyk U, Wetzig H, Schulz R, Richter M, et al. Redecoration of apartments promotes obstructive bronchitis in atopy risk infants-results of the LARS study. Int J Hyg Environ Health. 2003;206(3):1739.

50. Mir L. Indoor residential chemical emissions as risk factors for respiratory and allergic effects in children: a review. Environnement, Risques \& Santé. 2008;7(1):10-1.

51. Xu X, Nembhard WN, Kan H, Becker A, Talbott EO. Residential pesticide use is associated with children's respiratory symptoms. J Occup Environ Med. 2012;54(10):1281.

52. Fukuyama T, Tajima $Y$, Ueda H, Hayashi K, Shutoh $Y$, Harada T, et al. Allergic reaction induced by dermal and/or respiratory exposure to low-dose phenoxyacetic acid, organophosphorus, and carbamate pesticides. Toxicology. 2009;261(3):152-61.

53. Cushman JR, Street JC. Allergic hypersensitivity to the herbicide 2, 4-D in BALB/C mice. Journal of Toxicology and Environmental Health, Part A Current Issues. 1982;10(4-5):729-41.

54. Mamane A, Raherison C, Tessier J-F, Baldi I, Bouvier G. Environmental exposure to pesticides and respiratory health. Eur Respir Rev. 2015;24(137): 462-73.

55. Gascon M, Morales E, Sunyer J, Vrijheid M. Effects of persistent organic pollutants on the developing respiratory and immune systems: a systematic review. Environ Int. 2013;52:51-65.

56. Harris AM, Sempértegui $F$, Estrella $B$, Narváez $X$, Egas J, Woodin $M$, et al. Air pollution and anemia as risk factors for pneumonia in Ecuadorian children: a retrospective cohort analysis. Environ Health. 2011:10(1):93.

57. Mehta S, Shin H, Burnett R, North T, Cohen AJ. Ambient particulate air pollution and acute lower respiratory infections: a systematic review and implications for estimating the global burden of disease. Air Qual Atmos Health. 2013;6(1):69-83.

58. Organization WH. Air quality guidelines: global update 2005: particulate matter, ozone, nitrogen dioxide, and sulfur dioxide: World Health Organization; 2006.

59. Van Donkelaar A, Martin RV, Brauer M, Kahn R, Levy R, Verduzco C, et al. Global estimates of ambient fine particulate matter concentrations from satellite-based aerosol optical depth: development and application. Environ Health Perspect. 2010;118(6):847-55.

60. Luong LM, Phung D, Sly PD, Morawska L, Thai PK. The association between particulate air pollution and respiratory admissions among young children in Hanoi, Vietnam. Sci Total Environ. 2017;578:249-55.

61. Getaneh S, Alem G, Meseret M, Miskir Y, Tewabe T, Molla G, et al. Determinants of pneumonia among 2-59 months old children at Debre 
Markos referral hospital, Northwest Ethiopia: a case-control study. BMC pulmonary medicine. 2019;19(1):147.

62. Fisk WJ, Eliseeva EA, Mendell MJ. Association of residential dampness and mold with respiratory tract infections and bronchitis: a meta-analysis. Environ Health. 2010;9(1):72.

63. Miller JD. Health effects from mold and dampness in housing in western societies: early epidemiology studies and barriers to further progress. Fundamentals of mold growth in indoor environments and strategies for healthy living: Springer; 2011. p. 183-210.

64. Zheng X, Qian H, Zhao Y, Shen H, Zhao Z, Sun Y, et al. Home risk factors for childhood pneumonia in Nanjing, China. Chin Sci Bull. 2013;58(34):4230-6.

65. Zhuge $Y$, Qian $H$, Zheng $X$, Huang $C$, Zhang $Y$, Zhang $M$, et al. Residential risk factors for childhood pneumonia: a cross-sectional study in eight cities of China. Environ Int. 2018;116:83-91.

66. Nam H-S, Siebers R, Lee S-H, Park J-S, Kim Y-B, Choi Y-J, et al. House dust mite allergens in domestic homes in Cheonan, Korea. The Korean journal of parasitology. 2008;46(3):187.

\section{Publisher's Note}

Springer Nature remains neutral with regard to jurisdictional claims in published maps and institutional affiliations.

Ready to submit your research? Choose BMC and benefit from:

- fast, convenient online submission

- thorough peer review by experienced researchers in your field

- rapid publication on acceptance

- support for research data, including large and complex data types

- gold Open Access which fosters wider collaboration and increased citations

- maximum visibility for your research: over $100 \mathrm{M}$ website views per year

At $\mathrm{BMC}$, research is always in progress.

Learn more biomedcentral.com/submissions 